\title{
Potencial das Actinobactérias na Biodegradação de Hidrocarbonetos
}

\author{
Drielle Seabra Pereira \\ Universidade Severino Sombra, Curso de Biomedicina \\ drikka_seabra@hotmail.com \\ Rosana Canuto Gomes \\ Universidade Severino Sombra, Supervisora Acadêmica de Extensão \\ rosanacanutogomes@gmail.com \\ Luzia Teixeira A. S. Semêdo \\ Universidade Severino Sombra \\ Centro Universitário Geraldo Di Biase \\ luziasemedo@gmail.com
}

\begin{abstract}
Resumo: A crescente dependência mundial que o petróleo vem exercendo, tem acarretado sua introdução no meio ambiente, gerando contaminação $e$ destruição de diferentes ecossistemas. A biodegradação se mostra como uma alternativa extremamente viável para o biotratamento de ambientes contaminados por hidrocarbonetos de petróleo, através da decomposição de uma substância orgânica por ação microbiana, utilizando-se técnicas de bioaumentação, bioestimulação, landfarming, e fitorremediação. Dentre os micro-organismos, as actinobactérias são conhecidas pela produção de uma ampla variedade de moléculas bioativas, dentre elas enzimas que degradam hidrocarbonetos. Desta forma, a utilização destes micro-organismos elou suas enzimas, possuem grande potencial para minimizar os impactos gerados por substâncias recalcitrantes em a natureza, transformando-as em moléculas com pouca ou nenhuma toxicidade, através da utilização das mesmas como nutrientes ou por biotransformações.
\end{abstract}

Palavras-chave: Actinobactéria. Biodegradação. Biorremediação

\section{Actinobacteria Potential in Hidrocarbon Biodegradation}

\begin{abstract}
The increasing worldwide dependence on oil has led their introduction into the environment, causing pollution and destruction of ecosystems. The biodegradation appears as an extremely viable alternative for bio-treatment of environments contaminated with petroleum hydrocarbons through the decomposition of organic matter by microbial action, using techniques such as bioaugmentation, biostimulation, landfarming, and phytoremediation. Among microorganisms, the actinobacteriae are known for producing a wide variety of bioactives molecules, among which, enzymes that degrade hydrocarbons. Thus, the use of microorganisms and / or their enzymes have great potential to
\end{abstract}


minimize the impacts of recalcitrant substances in nature, transforming them into molecules with little or none toxicity, through the use of them as nutrients or by biotransformations.

Keywords: Actinobacteria. Biodegradation. Bioremediation

\section{Introdução}

O petróleo é uma mistura complexa de hidrocarbonetos, originado a partir da decomposição de matéria orgânica, principalmente o plâncton, ocasionada pela ação de bactérias em meios com baixo teor de oxigênio. Ao longo de milhões de anos, essa decomposição foise acumulando no fundo dos oceanos, mares e lagos e, pressionada pelos movimentos da crosta terrestre, transformou-se na substância oleosa denominada petróleo (Lucchesi, 1998).

O petróleo bruto possui em sua composição variações de compostos orgânicos tais como: cadeia de hidrocarbonetos, cujas frações leves formam os gases e as frações pesadas o óleo cru. A distribuição destes percentuais de hidrocarbonetos é o que define os diversos tipos de petróleo existentes no mundo (Petróleo 2009, Geologia do Petróleo 2009). Considerado uma fonte de energia não renovável, de origem fóssil e matéria prima da indústria petrolífera. O petróleo é um subsídio de grande importância mundial, principalmente em nossa atualidade. É difícil determinar algo que não dependa direta ou indiretamente do petróleo (Lucchesi, 1998).

Os solventes, óleos combustíveis, gasolina, óleo diesel, querosene, gasolina de aviação, lubrificantes, asfalto, plástico entre outros são os principais produtos obtidos a partir do petróleo (Petróleo, 2009).

De acordo com a predominância dos hidrocarbonetos encontrados no óleo cru, o petróleo é classificado em: alcanos, cicloalcanos, alquenos, cicloalquenos, alquinos e aromáticos (Geologia do Petróleo, 2009).

No século XIX tiveram início à exploração de campos e a perfuração de poços de petróleo. A partir de então, a indústria petrolífera teve grande expansão no mercado internacional, principalmente nos Estados Unidos e na Europa, especialmente após a invenção dos motores a gasolina e a óleo diesel (Petróleo, 2009).

Nos últimos anos tem se revelado cada vez mais ineficiente o transporte de petróleo no mundo, gerando acidentes que causam diferentes tipos de impactos em vários ecossistemas. Desta forma, se faz necessário o aprofundamento de diferentes tipos de ambiente contaminados (Freitas et al., 2001).

A biodegradação se mostra como alternativa extremamente viável para o biotratamento de ambientes contaminados por hidrocarbonetos de petróleo, através da decomposição de uma substância orgânica, pela ação de micro-organismos, como, por exemplo, as actinobactérias, reduzindo a toxicidade do ambiente contaminado (Jacques, Bento \& Antoniollim, 2007).

O biotratamento do ecossistema contaminado pode ser promovido por estimulação 
de micro-organismos nativos e por introdução de nutrientes e oxigênio ou através da inoculação de micro-organismos. Isto vai depender da diversidade do composto no ambiente contaminado (Jacques, Bento \& Antoniollim, 2007).

Existem hoje no mercado várias técnicas utilizadas para o biotratamento do combustível fóssil, técnicas estas baseadas no princípio da biorremediação (Trindade, 2002). A biorremediação in situ, no local do acidente e a ex situ, fora do local de contaminação. A escolha da técnica mais apropriada vai depender da disponibilidade do contaminante no meio ambiente (Jacques, Bento \& Antoniollim, 2007).

O presente trabalho tem como objetivo realizar o levantamento na literatura sobre as pesquisas desenvolvidas na área de biodegradação de hidrocarbonetos e as possíveis contribuições das actinobactérias, visando reunir informações importantes acerca dos pontos mais relevantes na área e oferecer suporte de estudo para futuras pesquisas.

\section{Classificação Química e Física dos Hidrocarbonetos do Petróleo}

Do latim petra (pedra) e oleum (óleo), o petróleo no estado líquido é uma substância oleosa, inflamável, menos densa que a água, com característica e cor variando entre o negro e o castanho-claro (Geologia do Petróleo 2009).

O petróleo é uma mistura complexa de inúmeros compostos orgânicos, com predominância quase absoluta de hidrocarbonetos. Sua composição química varia de acordo com sua procedência, e separá-los em componentes químicos puros ou misturas de composição conhecida é praticamente impossível. Essa composição pode mudar com o tempo, mesmo quando o óleo é retirado de um mesmo poço (Bento 2005).

No petróleo, além de uma mistura de hidrocarbonetos encontra-se associado pequena quantidade de nitrogênio, enxofre e oxigênio, sob forma gasosa, líquida ou sólida, em poros e fraturas, em geral de rochas sedimentares. Nos depósitos encontram-se também água salgada e uma mistura de gases responsáveis pela pressão que provoca a ascensão do petróleo através de poços perfurados. O petróleo líquido é também chamado óleo cru para distingui-lo do óleo refinado, produto comercial mais importante. O gás de petróleo (gás natural) é uma mistura de hidrocarbonetos leves, enquanto as formas semi - sólidas são compostas de hidrocarbonetos pesados (Bento 2005, Melo 2004, Petróleo 2009).

Os hidrocarbonetos são compostos orgânicos formados por carbono e hidrogênio. De acordo com sua estrutura são classificados em saturados, insaturados e aromáticos (Geologia do Petróleo, 2009).

Nos hidrocarbonetos saturados, os átomos de carbonos são unidos somente por ligações simples e ao maior número possível de átomos de hidrogênio. As moléculas contêm quantidade de átomos de hidrogênio suficiente para saturar os átomos de carbono. A cadeia pode ser observada na forma linear ramificada ou cíclica, interligadas ou não (Melo, 2004).

Parafínicos ou alcanos possuem cadeias retilíneas com ligações simples entre átomos de carbonos. O termo parafinas vem do latim parum $=$ pequena + affinis $=$ afinidades 
Algumas das propriedades físicas dos alcanos são: em temperatura ambiente de $25{ }^{\circ} \mathrm{C}$ até 4 átomos de carbono em cadeias linear estão na forma de gases, os alcanos de C5 até C17 são líquidos e os alcanos com mais de 18 átomos de carbono são sólidos (Geologia do Petróleo, 2009; Bento, 2005).

Os compostos aromáticos são hidrocarbonetos de cadeia fechada que apresenta na sua estrutura básica um anel com seis átomos de carbono com ligações duplas alternadas entre eles, esta unidade básica é chamada de benzeno, nos quais se verifica o fenômeno da ressonância (Geologia do Petróleo, 2009).

Os hidrocarbonetos que possuem dois ou mais anéis são denominados hidrocarbonetos policíclicos aromáticos (HPA), estes hidrocarbonetos são considerados os mais tóxicos componentes do petróleo e estão associados a efeito carcinogênico. Muitos dos HPA de baixo peso molecular são solúveis em água, aumentando o risco de contaminação (Netto et al., 1999).

\section{Petróleo}

O petróleo é uma fonte de energia não renovável, de origem fóssil. É uma das principais fontes de obtenção de energia para a civilização atual e o crescente aumento do consumo em todo mundo tem acarretado a sua introdução no ambiente. Nesse ambiente, processamse a maior parte do transporte e o desembarque do petróleo do mundo, atividades essas que aumentam a incidência de acidentes com tais produtos. Esses acidentes geram múltiplos tipos de impactos em diferentes ecossistemas mundiais através de eventos crônicos ou críticos de contaminação (Bento, 2005).

Quando o petróleo entra em contato com água do mar, vários processos físico-químicos e biológicos são passíveis de ocorrer e a intensidade de cada um deles varia ao longo do tempo (Souza e Coelho, 2004). De acordo com Bento (2005) existem alguns processos que ocorrem com o petróleo, tais como: espalhamento, evaporação, dissolução, dispersão, emulsificação, fotoxidação, sedimentação e biodegradação. Todos os processos de intemperização dependem das condições climáticas e do tipo de petróleo. Os acidentes ambientais relacionados aos combustíveis fósseis são eventos considerados comuns em todo mundo, estão diretamente interligado à crescente atividade econômica associada ao setor petrolífero.

Embora no estado natural apresenta-se de pouca utilização, o petróleo, quando refinado, produz combustíveis, lubrificantes, solventes, material de pavimentação e muitos outros produtos. Estes produtos derivados do petróleo respondem por mais da metade do suprimento total de energia do mundo, através da combustão direta quanto pela geração de eletricidade. Desta forma, fornecendo iluminação para muitos povos do mundo. Seus subprodutos também são utilizados para a fabricação de tecidos sintéticos, borracha sintética, sabões, detergentes, tinta, plásticos, medicamentos, inseticidas, fertilizantes, entre outros. Podem ser divididos em três partes: alifáticos, alicíclicos e aromáticos. São encontrados sob forma gasosa, líquida ou sólida, em poros e fraturas, em geral de rochas 
sedimentares (USP, 1999).

A velocidade de degradação do petróleo depende das características físicas e químicas do óleo, das condições do tempo e do clima. Nos sedimentos aquáticos, os hidrocarbonetos são degradados muito lentamente na ausência de luz e oxigênio (Geologia do Petróleo, 2009).

A degradação microbiológica possui uma seqüência preferencial de compostos a serem degradados (Souza e Coelho, 2004). A degradação do petróleo é bem mais lenta no sedimento do que na água, devido ao fato dos compostos mais leves persistirem mais tempo no sedimento. Os hidrocarbonetos sofrem uma adsorção nas partículas do material em suspensão, o que provoca forte tendência a acumularem-se nos sedimentos. Hidrocarbonetos policíclicos aromáticos (HPAs) são compostos presente em grande proporção na constituição do petróleo. Esses poluentes são considerados de prioridade ambiental e que devem ser frequentemente monitorados, devido ao fato de serem considerados como carcinogênicos, mutagênicos, teratogênicos, além de possuírem efeitos tóxicos aos seres vivos, pois apresentam a capacidade de se bioacumularem nas diferentes cadeias alimentares (Bento, 2005).

Atualmente, o setor petrolífero constitui a principal fonte energética, sendo responsável pela geração de $40 \%$ de toda energia mundial (Souza e Coelho, 2004).

\section{Derramamento de Petróleo}

O derramamento de petróleo normalmente acontece por causa de embarcações despreparadas, águas turbulentas que levam as embarcações contra pedras, plataformas furadas, explosões de poços, tanques com capacidade inferior ao conteúdo existente, entre outros. Ao entrar em contato com a água, as moléculas de menor peso molecular sofrem um forte processo de evaporação e dissolução durante as primeiras 24 e 48 horas. Desta forma, produz uma importante mudança na composição do petróleo, reduzindo o impacto na comunidade de organismos no ambiente marinho e terrestre. Após o derrame no mar, o petróleo fica sujeito a uma série de processos físicos, químicos e biológicos, acarretando a sua dispersão no meio e alterações em suas características físicas e químicas, sendo que a degradação pode apresentar-se muito diferente conforme a proximidade da linha da costa, provocando a morte dos seres vivos existentes, como peixes e corais, além de contaminar o solo fazendo com que a área localizada se torne improdutiva e tóxica (Bento, 2005). Dessa forma, as águas além de não sustentar a vida não servem ainda para consumo dos seres humanos, pois forma-se uma película sobre ela impossibilitando-a de ser utilizada e ainda quando chega à costa provoca também grandes prejuízos. Normalmente o derramamento de petróleo ocorre em maior grau nas águas (Melo, 2004).

\section{Biotransformação}

As biotransformações que provêem energia para o crescimento microbiano requerem a presença de doadores e aceptores de elétrons. Portanto, além de uma fonte de carbono, para que ocorra a biodegradação faz-se necessário a adição de nutrientes. Muitos contaminantes orgânicos podem satisfazer as exigências de crescimento, atuando como 
doadores de elétrons. Tais contaminantes sofrem oxidação como resultado de metabolismo microbiano (Melo, 2004).

Os compostos intermediários podem ser assimilados como uma fonte de carbono para o crescimento microbiano. Estes grupos funcionais como $\mathrm{NH}_{2},-\mathrm{NO}_{2} \mathrm{e}-\mathrm{SO}_{3}$ podem ser usados como fonte de nutrientes (Melo, 2004).

A oxidação pode acontecer aerobicamente ou anaerobicamente; em aerobiose o oxigênio agiria como o aceptor terminal, já em anaerobiose a combinações inorgânicas vai ser oxidado a nitrato, íons de metal, sulfatos, ou gás carbônico, embora seu valor energético seja menor (Melo, 2004).

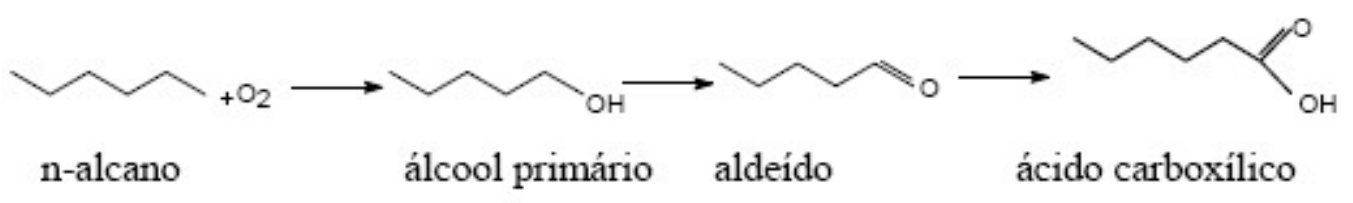

Figura 1. Biodegradação dos alcanos - Fonte: Análise química da degradação dos hidrocarbonetos de óleo diesel no Estuário da Lagoa dos Patos - Rio Grande/RS (Bento, 2005)

A biodegradação dos n-alcanos procede normalmente por um ataque monoterminal. A cadeia é atacada por uma monoxigenase que introduz um átomo de oxigênio molecular na molécula do composto alifático, então ocorre a formação de um álcool primário, que é oxidado em um aldeído, e finalmente em um ácido carboxílico (Figura 1) (Bento, 2005).

O ácido carboxílico será degradado via $\beta$-oxidação, formando ácidos graxos com dois carbonos a menos e acetil-coenzima A, com liberação eventual de $\mathrm{CO}_{2}$ (Bento, 2005).

A etapa de oxidação inicial com oxigênio não é possível sob condições anóxicas, o que aumenta a evidência de que os alcanos são anaerobicamente recalcitrantes, com exceção do metano (Melo, 2004).

Alguns ácidos graxos formados por este processo poderão ser tóxicos, podendo se acumular durante o processo de biodegradação (Bento, 2005).

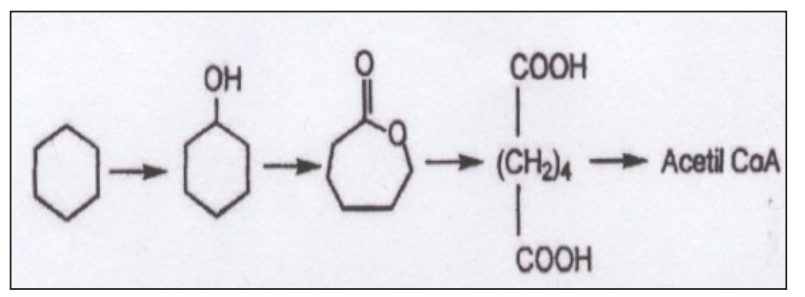

Figura 2. Processo de oxidação do ciclo alcano - Fonte: Avaliação do impacto do aumento das concentrações celulares na biodegradação de resíduos oleosos de petróleo (Melo, 2004). 
O ciclo alcano é particularmente resistente a biodegradação. Bento (2005) relata que há estudos que hidrocarbonetos cíclicos de até seis anéis condensados, que podem ser degradados lentamente.

Uma vez oxidados, o processo de deterioração destes compostos prossegue, havendo a clivagem dos anéis, dando origem a cetonas ou álcoois (figura 2) (Melo, 2004).

A rota de metabolização passa pela formação em alcoóis cíclicos, que em seguida sofrem uma desidrogenação, formando então, as cetonas correspondentes. Todo o processo é catalisado por enzimas ciclo-desidrogenases e monoxigenase. $\mathrm{Na}$ etapa subsequente ocorre a lactonização do anel mediada por monooxigenases levando a abertura do anel pela lactonahidrolase (Melo, 2004).

Os alcanos ramificados de cadeia aberta podem ser degradados por micro-organismos, porém, devido a sua configuração espacial, o acesso enzimático para que haja a oxidação torna-se prejudicado diminuindo a taxa de biodegrabilidade (Melo, 2004). Eles vão sofrer $\beta$-oxidação, como via degradativa, com formação de ácidos dicarboxílicos.

Os compostos alifáticos insaturados como os alcenos e alcinos são degradados aerobicamente através de mecanismos semelhantes aos alcanos. Porém as duplas e triplas ligações são mais quimicamente reativas e podem sofrer reações adicionais, como epoxidação (reação de transferência de oxigênio) ou hidratação. Há indícios que as duplas e triplas ligações podem ser hidratadas anaerobicamente para formar um álcool, que é convertido então mais adiante por via aeróbica. Os alcenos e alcinos são usados como fontes de carbono e energia por aeróbios e anaeróbios, ambos os tipos de organismo atacam a molécula inicial por hidratação (Melo, 2004).

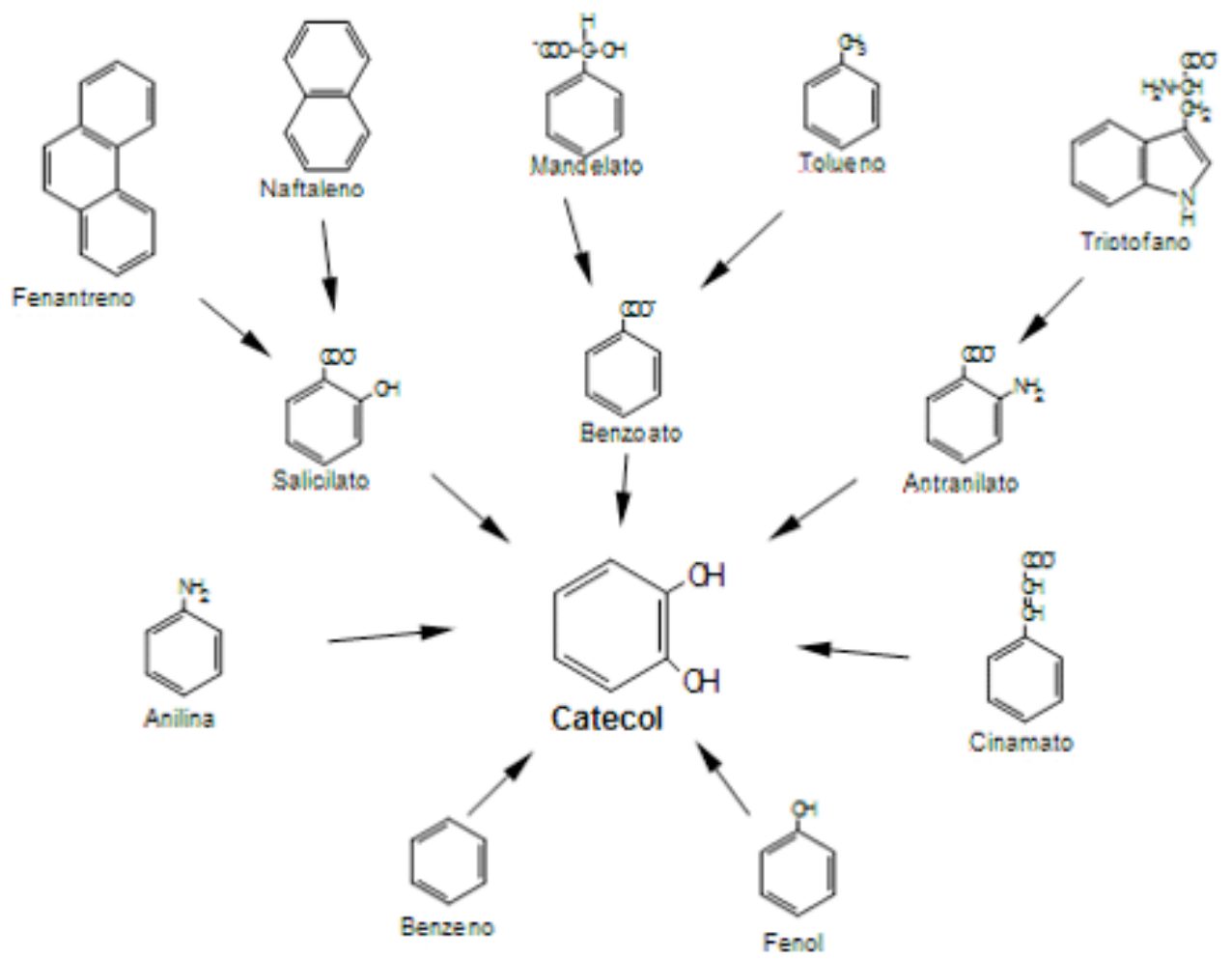

Figura 3. Exemplos da oxidação de diversos xenobióticos aromáticos num catecol (um intermediário oxidado) na primeira fase da degradação - Fonte: Vias de degradação de compostos aromáticos xenobióticos. Trabalho realizado pelo Instituto Superior Técnico (1999) 
Os hidrocarbonetos aromáticos de até três anéis são degradados mais facilmente (Bento, 2005). A biodegradação aeróbica de muitas classes de compostos aromáticos procede através da formação de um intermediário, o catecol (Figura 3). Os compostos aromáticos mais leves estão sujeitos à evaporação e à degradação microbiana no estado dissolvido. $\mathrm{O}$ ataque enzimático pode ser no substituinte alquil ou diretamente no anel (Melo, 2004).

As vias microbianas de biodegradação aeróbica de hidrocarbonetos de petróleo aromáticos podem ser divididas em três partes: na primeira fase, o substrato aromático é transformado em metabólito di-hidroxiaromático (tipicamente um catecol), pela introdução de grupos hidroxila por mono ou di-oxigenases; a segunda fase consiste na abertura do anel do catecol por di-oxigenases. Estas enzimas catalisam a adição de oxigênio molecular ao anel, quebrando uma das ligações carbono-carbono. A quebra do anel pode ocorrer em duas posições distintas: entre os grupos hidroxila (quebra intradiol ou orto) ou adjacentemente a um dos grupos hidroxila (quebra extradiol ou meta); na última fase do catabolismo dos hidrocarbonetos aromáticos, o produto resultante da abertura do anel é convertido em intermediários do metabolismo central acetil-CoA, oxalato e piruvato (Figura 4) (Instituto Superior Técnico, 2009).
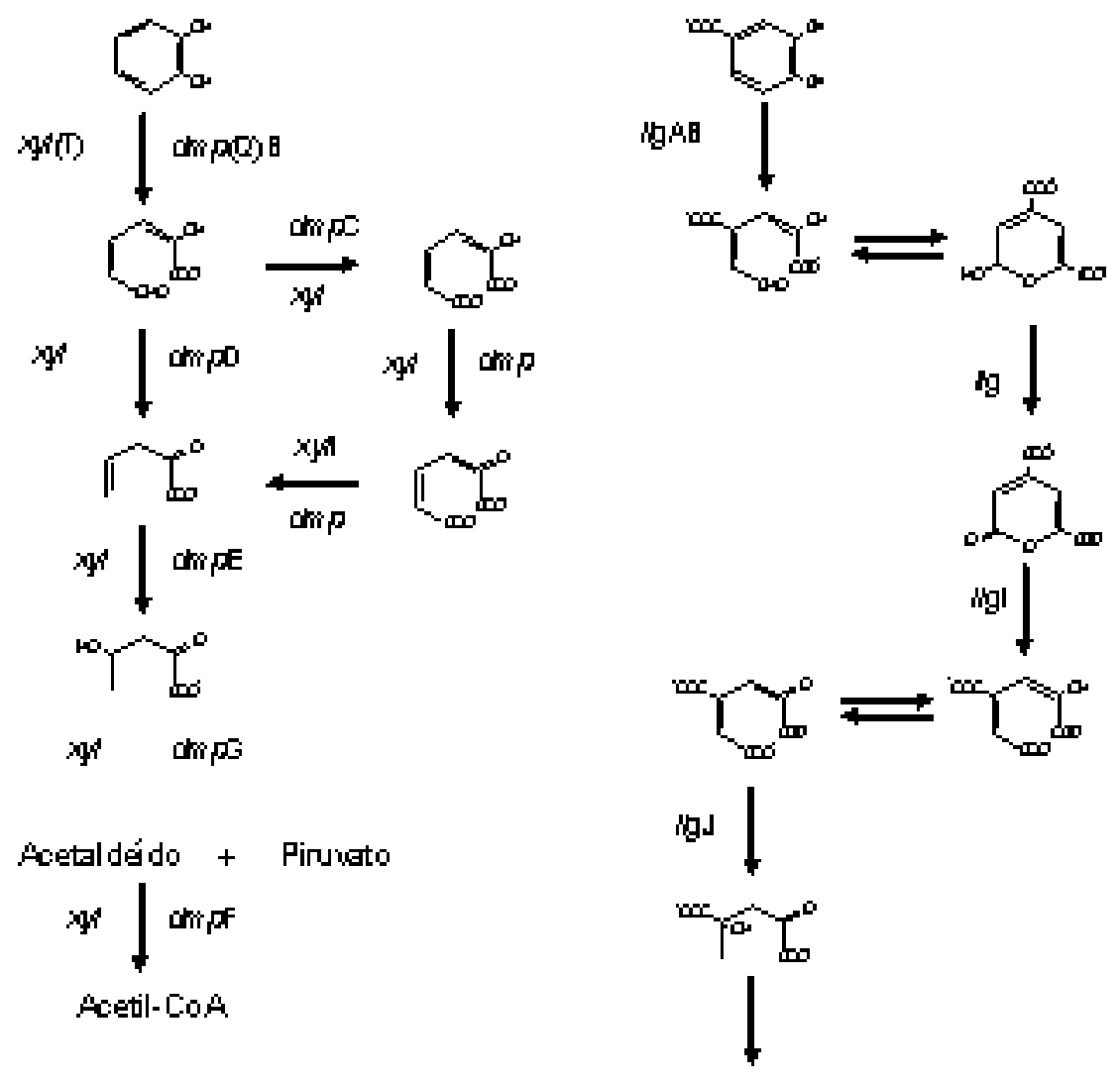

Oxaloacetato + Hruvato

Figura 4 . Vias de degradação de compostos aromáticos xenobióticos Fonte: Vias de degradação de compostos aromáticos xenobióticos. Trabalho realizado pelo Instituto Superior Técnico (2009) 
Anaerobicamente, o anel aromático não é oxidado, e sim reduzido. O intermediário neste caminho é uma ciclohexanona. $\mathrm{O}$ anel é aberto por hidratação da ciclohexanona. Porém pouco se sabe sobre o potencial metabólico dos anaeróbios pela biodegradação de compostos aromáticos. Alguns hidrocarbonetos aromáticos são degradados, dependendo do grupo funcional e do aceptor de elétrons terminal presente (Melo, 2004).

\section{Actinobactérias}

As actinobactérias, anteriormente denominadas actinomicetos, são bactérias Grampositivas com DNA rico em guanina e citosina. Estes micro-organismos podem ser encontrados no solo, águas e em outros ambientes, porém o solo é seu reservatório principal. Elas têm sido descritos como os principais produtores de antibióticos do solo, e também como um dos principais grupos microbianos produtores de enzimas de interesse comercial (Semêdo, 2004).

As actinobactérias são constituídas de uma região nuclear fibrilar e citoplasma granular, com ribossomos de até $12 \mathrm{~nm}$ de diâmetro. Dependendo do micro-organismo, tempo de crescimento e meio utilizado, o citoplasma pode conter uma variedade de outras inclusões (Williams, Sharples e Bradshaw, 1973).

A membrana plasmática é do tipo bicamada lipídica, obtida pela interação anfipática de lipídeos polares e proteínas de membrana que produzem uma matriz estável para incorporação de outros lipídeos funcionais. Os lipídios mais estudados são menaquinomas e pigmentos do tipo carotenóide, sendo que as menaquinonas estão principalmente envolvidas na cadeia de transporte de elétrons e na respiração (Williams, Sharples e Bradshaw, 1973).

A parede celular é constituída de peptídeoglicano junto com um ou mais polímeros associados, tais como ácidos teícoicos aniônicos e polissacarídeos neutros. As actinobactérias produzem filamentos finos, ramificados, denominado hifas, que se desenvolvem em micélio. O filamento pode ser bastante longo, embora seja curto em alguns, podendo ainda em alguns casos se fragmentar em pequenas unidades. As hifas individuais ou filamentos se parecem morfologicamente aos filamentos de fungos, porém, são mais estreitas (Semêdo, 1997).

O crescimento das actinobactérias ocorre principalmente pela extensão da parede celular como hifas ramificadas, que seguem uma cinética de crescimento aparentemente exponencial. Crescida as colônias, a parte mais distante da margem pode acumular várias classes de material de reserva como glicogênio, lipídeos e polifosfato (Williams, Sharples e Bradshaw, 1973).

Apesar da sua posição taxonômica junto às bactérias, a semelhança das actinobactérias com os fungos é evidente em três propriedades: o micélio das actinobactérias possui ramificações extensivas, características dos fungos; ambos formam micélio aéreo, bem como conídios e seu crescimento em cultura líquida raramente resulta em turgidez, mas sim se apresenta como massa ou "pellets" Exercem um importante papel na clivagem de compostos orgânicos nos ambientes naturais e desempenha um papel promissor na agricultura, como o gênero Frankia capazes de fixar nitrogênio atmosférico. Além disso, tem sido descrito também como causadores de doenças humanas, como: nocardioses, actinomicoses, e também nos vegetais e animais (Semêdo, 1997). 
As actinobactérias incluem gêneros que exibem um amplo limite de morfologia que se extende de cocos, passando à formas de hifas fragmentadas com um micélio altamente ramificado e diferenciado, como é o caso dos gêneros Streptomyces e Streptoverticillium (Semêdo, 1997).

As actinobactérias têm sido isoladas de diversos habitats incluindo solo, água doce e habitats marinhos. Eles têm sido extensivamente estudadas em laboratório, mas pouco se sabe sobre sua sobrevivência nestes ambientes naturais. Alguns gêneros formam esporos, os quais incluem zoosporos móveis e especialmente estruturas resistentes à dessecação, mas não exibem a organização e propriedades de resistência extrema dos endosporos; exceção apenas ao gênero dos Thermoactinomyces (Semêdo, 1997).

Os estreptomicetos normalmente possuem parede dos esporos mais espessa do que as hifas, sendo também mais hidrofóbicas, contribuindo com isso para a presença de um envelope externo. Os esporos são normalmente ornamentados e suas diferentes formas de ornamentação são utilizadas como critérios taxonômicos. Estes esporos também toleram a dessecação e o calor permanecendo viáveis por muitos anos, no entanto, a resistência não se compara com a dos endosporos bacterianos (Semêdo, 1997).

O gênero mais comumente isolado e amplamente estudado é o Streptomyces. No entanto outros gêneros têm sido observados e descritos na literatura (Semêdo et al., 2001).

Os grupos das actinobactérias nocardioformes formam hifas que eventualmente se fragmenta em elementos cocóides ou bacilares dando início a um novo micélio. Alguns dos gêneros incluídos neste grupo são Caseobacter, Mycobacterium, Rhodococcus e o próprio gênero Nocardia. Os esporos das actinobactérias possuem uma grande complexidade morfológica, incluindo a formação de esporos em partes definidas do micélio, como é o caso dos gêneros Actinoplanes, Ampullariella e Streptosporangium. Os Actinoplanes possuem hifas de micélio fino e são caracterizados por esporos em vesículas. Possuem pigmentos carotenóides. Os gêneros Dermatophylus e Geodermatophylus são caracterizados pela formação de um micélio que se divide transversalmente e longitudinalmente dando origem a um esporângio multilocular primitivo. Já o gênero Frankia, não apresenta micélio aéreo, sendo também importante na fixação biológica do nitrogênio, vivendo em simbiose em nódulos de raízes de plantas não leguminosas. O gênero Microsbispora não é resistente a ácidos e seus representantes podem ser mesofílicos ou termofílicos facultativos; os mesofílicos podem ser aeróbios ou anaeróbios facultativos. Thermomonospora é um gênero bastante peculiar, sendo aeróbios, não móveis, formando ramificações no micélio vegetativo e colônias coriáceas (cobertas) por micélio aéreo quando crescidas em meio contendo Agar (Williams, Sharples e Bradshaw, 1973).

A instabilidade genética é uma característica bastante comum encontrada nos actinobactérias. A maioria das características fenotípica relacionadas à diferenciação e metabolismo secundário são geneticamente instáveis, como: formação de micélio aéreo, pigmentação, esporulação, resistência a agentes genotóxicos (mitomicina C ou irradiação ultra-violeta) e resistência e/ou produção de antibióticos (Semêdo, 1997).

A taxonomia de actinobactérias é extremamente complexa. Ela não é possível utilizandose métodos tradicionais que levam em conta poucas características morfológicas e fisiológicas. Entretanto têm-se utilizado três abordagens principais que baseiam-se nos 
mais avançados métodos e técnicas de sistemática. Em primeiro lugar, a quimiotaxonomia que utiliza a caracterização de componentes específicas da célula tais como lipídios, ácidos aminados da parede, açúcar e proteínas, em segundo lugar, a taxonomia numérica se baseia na utilização do maior número possível de características fenotípicas. Em terceiro e último lugar, a sistemática molecular que utiliza métodos de hibridização de ácidos nucléicos DNA-DNA e DNA-RNAr, fago-tipagem, espectroscopia de massa de pirolisados e técnicas de seqüenciamento de RNAr para desvendar relações a níveis intra e inter-genéricos (Semêdo et al., 2004).

O procedimento tradicional usado para determinar o número e os tipos de actinobactérias presentes em amostras do meio ambiente envolve a técnica das diluições em placas, utilizando como substratos meios de culturas seletivos e /ou não seletivos. O resultado de tais experimentos é influenciado pela natureza da amostra do meio ambiente (exemplo: solo, sedimento ou água), eficácia do procedimento de extração e recuperação, meios de cultura seletivos e condições de cultivo, competições no isolamento em placas, incapacidade de identificação dos isolados corretamente e a fração da microflora que pode ser atribuída aos actinobactérias não cultiváveis (Semêdo et al., 2001).

As actinobactérias são consideradas as principais produtoras de antibióticos do solo, porém, além dos antibióticos, substâncias antivirais, antitumorais, imunomoduladores, compostos agrobiológicos e enzimas de alto valor comercial, também têm sido isoladas (Semêdo et al., 2004).

Para o isolamento de actinobactérias raras, os métodos utilizados envolvem o uso de pressões seletivas como adição de antibióticos ou mistura de antibióticos (Semêdo 1997).

A heterogeneidade bioquímica das actinobactérias, sua diversidade ecológica e sua capacidade excepcional para a produção de metabólicos secundários a tornam um bom alvo para a produção de enzimas, desempenhando novas atividades e especificidades, sendo uma fonte promissora para uma ampla faixa de importantes enzimas (Semêdo, 1997).

As enzimas das actinobactérias são capazes de degradar compostos nitrogenados orgânicos, carboidratos, vários esteróides como o colesterol, uma variedade de compostos aromáticos, acetileno e muitos outros. Eles também são capazes de utilizar o agar, a borracha, parafinas e ligninas, substâncias que são reconhecidamente resistentes ao ataque da grande maioria de bactérias e fungos. Algumas dessas enzimas já têm sido produzidas em escala industrial, mas a grande maioria ainda não (Semêdo et al., 2000).

\section{Biodegradação}

\section{Biodegradação: panorama geral}

À crescente dependência que o mundo atual está apresentando pelo petróleo e seus derivados, sejam eles para a manutenção de suas atividades industrial ou não, vem ocasionando a contaminação de solos e do ambiente hídrico por hidrocarbonetos, geralmente por perdas ou rompimentos de dutos, ou por acidentes ocorridos no seu transporte. Tendo efeito pronunciado sobre as propriedades do ambiente contaminado, com processos de 
toxidade sobre os micro-organismos e mortandade dos organismos (Mariano, 2001). Esses acidentes causam diferentes tipos de impactos em vários ecossistemas através de eventos de contaminação, desta forma gerando a necessidade de um estudo constante desse ambiente (Bento, 2005).

A técnica de biodegradação se mostra como alternativa extremamente viável para o biotratamento de ambientes contaminados por hidrocarbonetos de petróleo (De Oliveira, 2001).

A biodegradação é a decomposição de uma substância orgânica, como o petróleo, pela ação de organismo vivo, normalmente micro-organismo e, em especial, as bactérias (De Oliveira, 2001). Ela ocorre em diferentes etapas dependente da natureza e do hidrocarboneto presente (Das e Chandran, 2011).

Estudos moleculares recentes, demonstraram que a contaminação por hidrocarbonetos e o tratamento pela técnica de biopilhas (escavação, aeração e fertilização) em solos árticos modifica drasticamente a comunidade microbiana do solo, favorecendo os aeróbios que são capazes de degradar vários compostos de hidrocarbonetos como exemplo: Pseudomonas, Rodococcus, Sphingomonas e Caulobacter. A dominância desses organismos variam com o tempo de acordo com a mudança na disponibilidade e qualidade de hidrocarbonetos e nutrientes durante a biorremediação (Yergeau et al., 2012).

O processo biológico de biodegradação envolve todos os fenômenos de quebra dos componentes orgânicos do petróleo para componentes mais simples e de menor peso moleculares ou mais polares, através de micro-organismo (Melo, 2004).

A biodegradação completa dos hidrocarbonetos resulta na formação de dióxido de carbono e água; este processo biológico envolve dois fatores essenciais: a nutrição e a respiração. Os micro-organismos fazem uso da matéria orgânica constituída de um resíduo, seja ele sólido ou líquido, servindo-se de uma boa parte desta para seu crescimento e reprodução. O restante é oxidado por meio da respiração, aproveitando sua energia e compensando ao meio, elementos na forma de subprodutos do seu metabolismo. Desta maneira, carbono, nitrogênio e fósforo, que faziam parte das moléculas orgânicas dos resíduos, são devolvidos ao meio (ar, água, solo) na forma de compostos mais simples, como gás carbônico, fosfatos, nitratos, entre outros (Silva, Melo e Souza, 2009).

A biodegradação do petróleo por populações naturais de micro-organismos representa um importante instrumento pelo qual as substâncias poluentes são degradadas e eliminadas do meio ambiente. Isto decorre da capacidade de adaptabilidade microbiana; dessa forma vem crescendo o interesse pelos estudos de biorremediação, que fornece tecnologia baseada no uso de micro-organismos vivos para remover poluentes de solos e águas, preferencialmente in situ (EMBRAPA, 2008). Recentemente Hidayati e Tachibana (2012), demonstraram que Fusarium sp092 foi eficiente na degradação das frações alicíclicas de óleo cru em condições marinhas.

Alguns desses compostos do petróleo são facilmente evaporados ou biodegradados, enquanto outros persistem recalcitrantes por um bom tempo na natureza (Bento, 2005).

Os organismos podem metabolizar somente um número limitado de hidrocarbonetos isoladamente, de forma que é requerida uma mistura de populações com capacidade enzimática para degradar todos os hidrocarbonetos encontrados no petróleo (Mariano, 
2001). As taxas de biodegradação do petróleo são influenciadas principalmente pela temperatura, disponibilidade de nutrientes, $\mathrm{pH}$ e níveis de oxigênio (Melo, 2004).

Abiodegradação doshidrocarbonetos pode ocorrernuma faixa de temperatura relativamente grande de $0{ }^{\circ} \mathrm{C}$ a $70{ }^{\circ} \mathrm{C}$. De um modo geral, a baixa temperatura a viscosidade do óleo aumenta e a volatilização dos alcanos de cadeia curta é reduzido, o que leva a um processo de biodegradação mais lento. A atividade enzimática apresenta um melhor metabolismo para os hidrocarbonetos a uma temperatura máxima de $30{ }^{\circ} \mathrm{C}$ a $40{ }^{\circ} \mathrm{C}$. Outro fator a ser considerado no solo é a variação do $\mathrm{pH}$ com valores de 2,5 a 11 para diferentes tipos de solos. A maioria das bactérias e fungos apresenta uma melhor taxa de desenvolvimento em $\mathrm{pH}$ próximo ao neutro e de uma condição nutricional suficiente para o crescimento bacteriano, podendo ocorrer o dobro da taxa de biodegradação com a correção do $\mathrm{pH}$ do solo. A presença de oxigênio gera uma rápida oxidação dos hidrocarbonetos e outros compostos do petróleo. Sob condições anaeróbicas, a biodegradação é mais lenta e normalmente efetuada por bactérias sulfato-redutoras (Bento, 2005).

O contato óleo-água, devido à relativa insolubilidade do óleo na água, controla a velocidade de oxidação e da degradação. Os dispersantes são substâncias utilizadas para reduzir à tensão superficial entre a água e o óleo, auxiliando a formação de gotículas menores, as quais tendem tanto a se movimentar na coluna d'água, como permanecer em suspensão na superfície, acelerando o processo natural de degradação e de dispersão, favorecendo desta forma a biodegradação. Os dispersantes são formulações químicas de natureza orgânica, destinadas a reduzir a tensão superficial entre o óleo e a água, auxiliando a dispersão do óleo em gotículas no meio aquoso. São constituídos por ingredientes ativos, denominados surfactantes, cuja molécula é composta por uma cadeia orgânica, basicamente apolar, com afinidade por óleos e graxas (oleofílica) e uma extremidade de forte polaridade, com afinidade pela água (hidrofílica). Além dos surfactantes, os dispersantes também são constituídos por solventes da parte ativa que permitem a sua difusão no óleo (Melo, 2004).

Apesar das bactérias serem provavelmente as maiores responsáveis pela biodegradação de hidrocarbonetos no ambiente, os fungos e as leveduras, as cianobactérias e as algas apresentam capacidade de biodegradação. Como a biodegradação de hidrocarbonetos para $\mathrm{CO}_{2}$ envolve uma reação de oxidação, os organismos, em sua maioria, são aeróbios. $\mathrm{O}$ destino dos hidrocarbonetos, além da produção de $\mathrm{CO}_{2}$ na biodegradação total, pode também oferecer caminhos alternativos. Eles podem ser armazenados e alguns podem ser incorporados como biomassa, porém os produtos parcialmente oxidados podem ser mais tóxicos e mutagênicos que o hidrocarboneto original. Portanto existe a preocupação que ocorra um aumento temporário na toxidade e mutagenicidade durante o processo de biodegradação (Melo, 2004). 


\section{Biorremediação de ambientes contaminados}

A biorremediação de ambientes contaminados consiste no uso de espécies microbianas para biodegradar substâncias, muitas vezes perigosas para os seres vivos, transformandoas em produtos com pouca ou nenhuma toxicidade, como dióxido de carbono, água e biomassa. Embora a maioria dos compostos orgânicos sejam degradados naturalmente, certos compostos, principalmente algumas macromoléculas são persistentes no meio ambiente. Fatores que contribuem para essa persistência ainda tem sido discutido, porém, podemos ressaltar a insolubilidade, tamanho da molécula ou estrutura polimérica, toxicidade e origem (De Oliveira, 2001; Hurst et al., 1997).

Diferentes micro-organismos degradam diversas substâncias e alguns sobrevivem em condições extremante adversas, o tratamento biológico desses ambientes contaminados pode ser promovido por estimulação de micro-organismos nativos através da introdução de nutrientes e oxigênio ou podem ser obtidos através da inoculação de outros microorganismos (Menezes, 2009).

Devido à grande diversidade de compostos orgânicos no ambiente contaminado, o estudo de biorremediação está cada vez mais específico e tem se demonstrado de suma importância para o tratamento desses ecossistemas. As técnicas de biorremediação são direcionadas a estimulação dos micro-organismos utilizando os contaminante como nutrientes (De Oliveira, 2001).

A biorremediação é um processo que compreende diferentes etapas, podendo ser complementado com reações enzimáticas por muitas espécies de micro-organismos. As vias metabólicas e a de degradação diferem em função da linhagem bacteriana e das enzimas específicas envolvidas. Para se obter um biotratamento eficaz, normalmente é utilizado consórcios microbianos. As diferentes estratégias para a biorremediação visam aumentar a população microbiana gerando condições ambientais favoráveis para o seu desenvolvimento (Melo, 2004).

A medida corretiva mais propícia a ser adotada depende de diversos fatores, dentre eles, os tipos de micro-organismos presentes, e as condições locais do ambiente contaminado (De Oliveira, 2001).

Não há critérios definidos para escolha de uma determinada técnica de biorremediação, a complexibilidade dos problemas de contaminação pode requerer a combinação de diversas técnicas. A tabela 1 resume os fatores químicos e biológicos importantes na escolha da melhor tecnologia para a recuperação de sítios contaminados (Melo, 2004).

Os micro-organismos podem fazer uso do próprio poluente como fonte de alimento, das quais obtêm nutrientes e energia, consumindo-o à medida que crescem e transformando-o em biomassa e compostos como o dióxido de carbono e água (Quental, 2002). Em geral, é preferível aumentar a atividade metabólica dos micro-organismos presentes ao invés de utilizar micro-organismos exógenos, já que os micro-organismos nativos estariam mais adaptados ao meio, e em princípio, mais efetivos que os demais. Porém, se o meio for estéril, ou se a população microbiana presente não degradar os contaminantes existentes, o uso de micro-organismos exógenos deve ser considerado como alternativa positiva na biorremediação (Melo, 2004). 
Tabela 1. Fatores preponderantes na escolha do tratamento

\begin{tabular}{c|c}
\hline Fatores químicos e biológicos favoráveis. & Fatores químicos e biológico não favoráveis. \\
\hline Pouca quantidade de contaminantes. & $\begin{array}{c}\text { Grande quantidade de contaminante e/ou uma mistura } \\
\text { complexa de compostos orgânicos }\end{array}$ \\
\hline Quantidade de micro-organismo favorável & Quantidade de micro-organismo desfavorável \\
\hline Concentrações não tóxicas & Pouca atividade microbiana. \\
\hline População microbiana complexa & pH extremos \\
\hline ph 6 a 8 & $\begin{array}{c}\text { Alta concentração tóxica } \\
\text { (baixa permeabilidade) }\end{array}$
\end{tabular}

Se o processo ocorrer sob condições aeróbicas, nas reações bioquímicas do microorganismo, o oxigênio atua como receptor universal de hidrogênio. Por outro lado, em condições anaeróbicas, este processo torna-se mais complexo, pois várias substâncias tornam-se receptores de hidrogênio. Desta maneira, o mesmo composto pode atuar como receptores ou doadores de hidrogênio dependendo das condições ambientais que se encontram (Melo, 2004). Na presença de oxigênio e outros elementos nutricionais, os micro-organismos podem converter a maioria dos contaminantes orgânicos em dióxido de carbono, água e massa celular microbiana (Hurst et al., 1997).

No processo anaeróbico, ou seja, na ausência de oxigênio, o carbono não é metabolizado por completo, apresentando-se na forma intermediária. Nesta condição é produzido o metano, pequenas quantidades de dióxido de carbono. Em condições de redução, o sulfato é convertido em sulfeto ou enxofre e o nitrogênio molecular através da redução do nitrato, gás sulfúrico e mercaptanas (Cunha e Bianchini, 2009; Hurst et al., 1997). O metano composto presente na formação do gás natural (Quental, 2002). As mercaptanas são compostos orgânicos de fórmula geral $\mathrm{RSH}$, aonde $\mathrm{R}$ é um radical orgânico; S é um átomo de enxofre e $\mathrm{H}$ é um átomo de hidrogênio. As mercaptanas são produzidas pela ação de bactérias anaeróbicas sobre proteínas que contenham enxofre, este processo ocorre naturalmente sendo responsáveis pelo o odor (Mogiana, 2009). Algumas vezes os contaminantes podem ser degradados a intermediários ou a produtos finais, que podem ser menos, igualmente, ou mais perigosos do que o contaminante original (Hurst et al., 1997).

Os substratos para os organismos anaeróbicos são mais restritos que os para os aeróbicos. A completa oxidação destes substratos é obtida por uma série de etapas e combinações de atividades de uma diversidade de micro-organismos, dentre as quais se encontram as fermentadoras, as nitratos redutoras, as sulfatos redutoras e as metanogênicas. Sob condições de ausência de oxigênio a degradação de grande parte da matéria orgânica pode ocorrer através da metanogênese (Cunha e Bianchini 2009).

O processo anaeróbico no ambiente ocorre por meio de dois estágios, dos quais, o primeiro atua uma diversidade de bactérias anaeróbicas heterogêneos, que são agrupadas sob denominação de bactérias formadoras de ácidos. No segundo estágio, ocorre o 
processo de hidrólise enzimática, pela ação de bactérias que transformam proteínas em polipeptídios e depois em ácidos aminados simples, os carboidratos em açucares e as gorduras em glicerol. Os ácidos aminados, açúcares e glicerol formados por hidrólise enzimática são solúveis em água e convertidos em ácidos orgânicos através do processo de fermentação, observado na figura 5. Desta forma, as bactérias metanogênicas utilizam estes ácidos orgânicos convertendo em dióxido de carbono e metano. Alguns alcoóis derivados da fermentação de carboidratos, por meios das bactérias metanogênicas podem ser convertidos em metano e dióxido de carbono (Cunha e Bianchini, 2009).

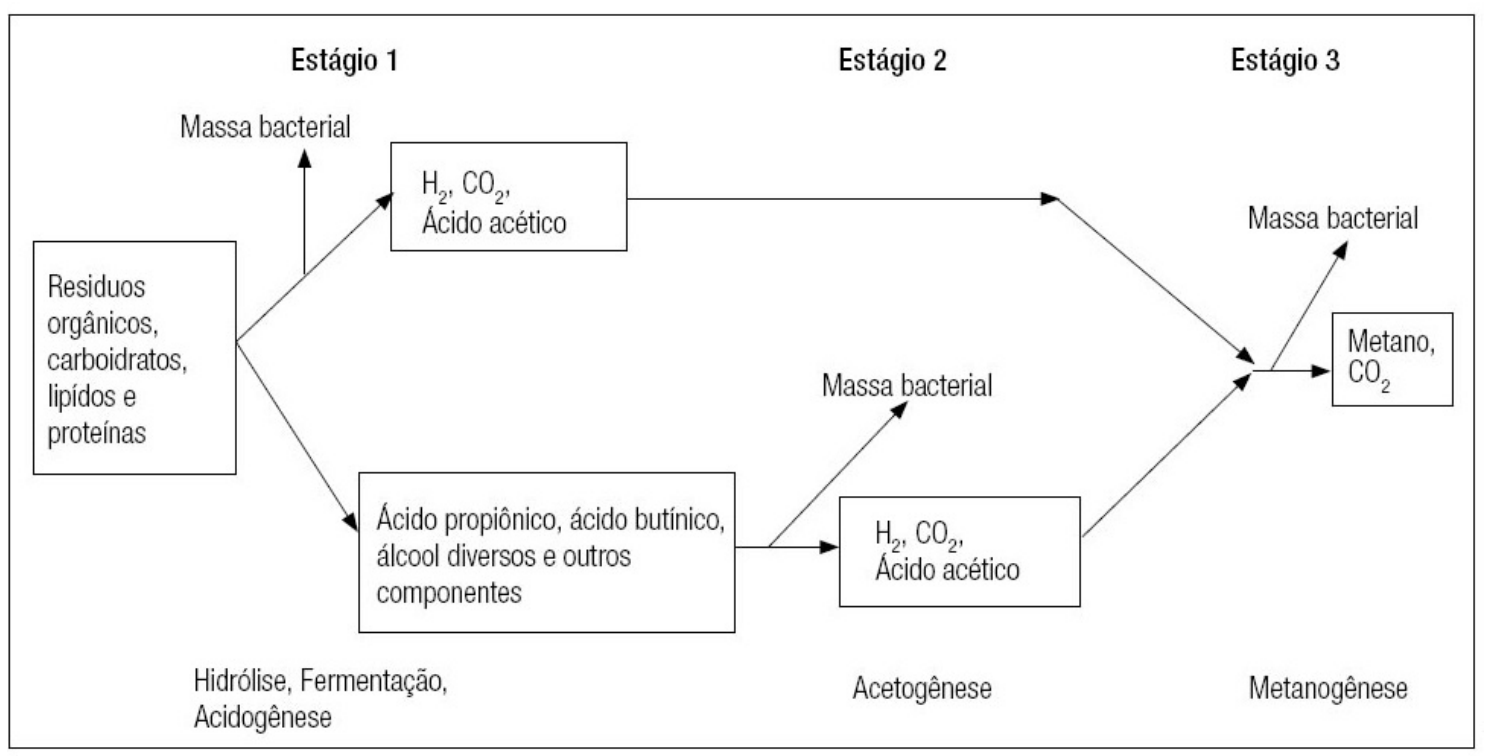

Figura 5. Formação do metano

Fonte: http://www.scielo.br/img/revistas/qn/v28n2/23653f2.gif\&imgrefurl

De um modo geral, no primeiro estágio o dióxido de carbono atua como receptor de hidrogênio, sendo reduzido a metano por adição do hidrogênio derivado dos ácidos orgânicos. No segundo estágio o ácido acético, que é o principal produto intermediário produzido pela fermentação, é convertido em dióxido de carbono e metano (Cunha e Bianchini, 2009).

O poluente a ser degradado, pode ainda ser co-metabolizado pelos micro-organismos, o que significa que não é a principal fonte de nutriente, mas que é consumido juntamente com a fonte principal de alimento (Hurst et al., 1997). Nestes casos, é comum fornecer compostos de fácil degradação, estimulando assim o seu crescimento (Quental, 2002).

O uso da biorremediação como processo de limpeza de sítios contaminados através da cinética microbiana é de tal forma dinâmica que os produtos liberados por algumas bactérias podem ser alimento para outras, sendo os poluentes transformados em compostos progressivamente mais simples. O objetivo da biorremediação é minimizar os poluentes, liberando apenas substâncias inertes como o dióxido de carbono, água e a biomassa molecular (Quental, 2002). 
O uso da técnica de biorremediação para reduzir a concentração e/ou a toxicidade dos poluentes, pode ser promissor (Rosa e Triguis 2006). Estas envolvem variações de tratamentos in situ (no local) e ex situ (fora do local) que pode envolver inúmeros procedimentos (Melo, 2004).

A técnica de biorremediação in situ no solo possibilita o tratamento sem escavação do meio ambiente e evita os problemas associados ao transporte de material contaminado, diminuindo assim, os custos. O controle do processo neste tipo de tratamento pode ser mais difícil que o tratamento ex situ podendo resultar num processo mais lento, além da dificuldade em garantir a qualidade do produto final (Hurst et al., 1997).

A técnica de biorremediação ex situ, apesenta como vantagem a rapidez no tempo de tratamento do que comparado $a$ in situ, esta envolve a remoção do material contaminado para outra área, elevando os custos do tratamento, e os riscos de acidentes dependendo do resíduo a ser tratado (Hurst et al., 1997).

A implementação da biorremediação ex situ evita as dificuldades impostas pela hidrogeologia do sítio contaminado. Geralmente a biodegradação in situ aplica-se onde a hidrogeologia do sítio permite o transporte de água e nutrientes e/ou oxigênio através da sub-camada e assegura a contenção dos contaminantes. Embora exista compostos orgânicos que não sejam passíveis de serem biodegradados, as técnicas de biorremediação têm sido utilizadas com sucesso para remediar diferentes ecossistemas contaminados. A taxa com que os micro-organismos degradam os contaminantes é influenciada pela presença e concentração destes contaminantes, fornecimento de oxigênio e nutrientes, umidade e temperatura. Geralmente, isto significa, que existe a necessidade de combinar oxigênio, nutrientes e umidade, além de controle de temperatura e pH (Melo, 2004; Hurst et al., 1997).

A biorremediação não pode degradar os contaminantes inorgânicos, mas pode ser utilizada para trocar o estado de valência destes compostos e promover a absorção, imobilizar, precipitar, retirar, acumular e concentrar em micro ou macro-organismo (Santos et al., 2007).

\section{Bioaumentação}

A capacidade dos micro-organismos em degradar compostos orgânicos e a taxa na qual a degradação ocorre depende da interação de numerosos fatores, já mencionados acima. Existem dois métodos para aumentar a taxa de biodegradação (Semêdo, 2004).

Estimulação da população indígena (bioestimulação)

Bioestímulo consiste no aumento da atividade da população microbiana autóctone através adição de nutrientes e/ou aceptores finais de elétrons, como o oxigênio (processo aeróbio envolve a oxidação de substratos pelas enzimas oxigenases) ou nitrato.

Adição de micro-organismo selecionado (bioaumentação). 
O bioaumento consiste na re-inoculação do ambiente contaminado com micro-organismos autóctones diretamente isolados do mesmo ambiente, aumentando a atividade biológica específica e, consequentemente, a taxa de biorremediação do ambiente (Santos et al., 2007).

A adição de substâncias e nutrientes ao sítio contaminado torna as características físicas do mesmo, mais propício a biorremediação. $\mathrm{O}$ ambiente com uma baixa permeabilidade é mais difícil de aerar, e frequentemente formam aglomerados, dificultando a distribuição de umidade, ar, adição de nutrientes (bioestímulo) e de micro-organismos (bioaumento). Desta forma, materiais de baixa densidade são adicionados ao ambiente para reduzir a sua densidade, aumentando a porosidade e possibilitando maior difusão de oxigênio. Estes elementos são adicionados ao solo contaminado via veículo líquido (água) sendo possível à utilização de sistemas aeróbios e/ou anaeróbios mediante a exigência da microbiota existente (Fernandes e Alcântara, 2009).

A bioaumentação não é uma ferramenta a ser utilizada em todos os casos de degradação, geralmente é utilizada para o tratamento de compostos que são vagarosamente decompostos, quando o poluente é tóxico para a microbiota indígena, após contaminação com hidrocarbonetos (Santos et al., 2007).

Para que a aplicação da técnica tenha sucesso é necessário que se isole e caracterize o micro-organismo utilizado e verifique a sobrevida deste após a liberação na ambiente (Semêdo, 2004).

\section{Bioventilação}

A bioventilação é uma tecnologia que estimula a biodegradação natural in situ de qualquer composto degradável aerobicamente no solo, através do fornecimento de oxigênio, desde que o solo possua atividade microbiana. Na técnica de bioventilação, o fornecimento do oxigênio é feito em fluxo baixo para sustentar a população microbiana. O oxigênio é fornecido através da injeção do ar na contaminação residual de solos e águas subterrâneas contaminadas, estimulando o crescimento e atividade de degradação dos micro-organismos (Fernandes e Alcântara, 2009).

\section{Fitorremediação}

A fitorremediação é uma técnica biológica atualmente bastante promissora, que tem por base a utilização de algumas espécies de plantas, para remover, transferir, estabilizar e destruir contaminantes orgânicos e inorgânicos presentes no solo e sedimentos, podendo ser aplicada como método de contenção, destruição ou extração de vários tipos de contaminantes. Os ambientes sob vegetação apresentam uma biodegradabilidade mais acelerada e completa se comparada com áreas não plantadas. Algumas plantas tem a capacidade de produzirem enzimas que transformam metabolicamente os contaminantes orgânicos contribuindo desta forma para sua oxidação mais rápida pelos micro-organismos presentes no solo (Fernandes e Alcântara, 2009).

Os mecanismos envolvidos na fitorremediação incluem: 
Fito-acumulação: Retirada dos contaminantes pelas raízes das plantas e a translocação/ acumulação de contaminantes dentro de folhas germinadas.

Fito-degradação: É a metabolização dos contaminantes, dentro dos tecidos das plantas. As plantas possuem enzimas, como as dehalogenases e oxigenases, que auxiliam a catalisar a degradação.

Fito-estimulação: É o fenômeno de produção de um composto químico pelas plantas para imobilizar contaminantes na interface de raízes e solo (Semêdo, 2004).

As principais desvantagens desta técnica são a sua característica sazonal e a possibilidade de provocar a bioacumulação em animais (Castelo-Grande, Augusto e Barbosa, 2009).

\section{Landfarming}

Landfarming é uma técnica aplicada a biorremediação de solos contaminados com compostos orgânicos, que são eliminados por biodegradação. Esta tecnologia consiste na aplicação do contaminante em forma líquida ou sólida na camada arável do solo (Melo, 2004). O resíduo é aplicado à superfície de uma área e misturado com o solo por meio de equipamentos convencionais, como tratores equipados com arados e/ou grades (Secretaria do Estado do Meio Ambiente, 2009), de modo a formar superfícies de pequena espessura onde se promove a estimulação da atividade microbiana através da adição de nutrientes, minerais ou mistura de ambos (Melo, 2004). Se a profundidade da contaminação for inferior a $90 \mathrm{~cm}$ é possível estimular a atividade biológica sem escavação de solo (CasteloGrande, Augusto e Barbosa, 2009).

A técnica Landfarming é a mais utilizada no tratamento de rejeitos sólidos da indústria petrolífera, por sua simplicidade e baixo custo (Melo, 2004). Em ambientes aquáticos essa técnica se dá pela incorporação ao solo sob condições controladas, para promover a degradação e imobilização dos contaminantes presentes (Secretaria do Estado de Meio Ambiente, 2009). O solo é arado e gradeado para promover a mistura uniforme do contaminante. Essa camada pode atingir 18 polegadas, dependendo da profundidade de incorporação dos resíduos. A pulverização do solo pela aração facilita o espalhamento do solo com contaminante pelo vento. Para que isso seja evitado, o solo deve ser mantido úmido (Melo, 2004; Semêdo, 2004).

\section{Biopilhas}

O tratamento por biopilhas é um processo de grande escala, no qual o solo é escavado e misturado com solo corrigido e colocados em uma área para tratamento (Semêdo, 2004).

As leiras biológicas - são utilizadas com o mesmo propósito da técnica de landfarming diferindo no modo de promover o arejamento (Barbosa et al., 2009).

Otratamento, geralmente, érealizado emárea coberta ou contido com umforro impermeável, para minimizar o risco de contaminação reduzindo a lixiviação do contaminante para águas e solos subterrâneos. A drenagem pode ser tratada em um biorreator, antes de ser reciclada. As pilhas e células de solo, normalmente possuem um sistema de distribuição 
de ar à vácuo ou pressão positiva, onde o ar passa através do solo. As pilhas de solo não devem ultrapassar 3 metros de altura (Semêdo, 2004).

Este método tem como objetivo simular a atividade microbiana aeróbia acelerando o processo de degradação do poluente pela aeração, adição de nutrientes e correção de umidade. A utilização dessa tecnologia, em relação à técnica in situ, apresenta a vantagem de manipular facilmente os fatores ambientais que influenciam a biodegradação do contaminante tais como $\mathrm{pH}$, temperatura, concentração de nutrientes, umidade e aeração (Santos et al 2007).

\section{Compostagem}

A técnica da compostagem é um procedimento ex situ, que foi desenvolvida com a finalidade de acelerar com qualidade a estabilização (também conhecida como humificação) do contaminante orgânico. Em a natureza a humificação ocorre sem prazo definido, dependendo das condições ambientais e da qualidade dos resíduos orgânicos (Ministério da Agricultura, 2005).

A compostagem é uma maneira econômica, higiênica e ecológica de manejo de resíduos. Um dos requisitos principais para que um sistema de compostagem possa ser possível é a sua utilização na agricultura (Semêdo, 2004).

O processo pode ser utilizado para transformar diferentes tipos de substâncias orgânicas, através da biodegradação dos sítios contaminados convertendo-os em subprodutos com pouca ou nenhuma toxidade. O solo é escavado e misturado com agentes dispersantes e aditivos orgânicos, tais como aparas de madeira ou resíduos vegetais (Ministério da Agricultura, 2005). Pode se obter a eficiência máxima de degradação, mantendo a mistura em condições constantes de concentração de oxigênio, $\mathrm{pH}$ e temperatura. Este processo pode ser aplicado em solos ou sedimentos com compostos orgânicos que sejam biodegradáveis. Os custos associados a este tratamento variam conforme o volume de solo e tipo de contaminantes a serem tratados (Castelo-Grande, Augusto e Barbosa, 2009).

\section{Biodegradação de Hidrocarbonetos por Actinobactérias}

As bactérias são os agentes mais ativos na degradação do petróleo, sendo as primeiras a degradar quando ocorre derramamento de óleo no meio ambiente. Várias bactérias são conhecidas ser exclusivas na rapidez em degradar hidrocarbonetos, além dos fungos. $\mathrm{Na}$ atualidade, a extensão com que as bactérias, fungos filamentosos e leveduras participam na biodegradação de hidrocarbonetos de petróleo tem estudo limitado, estando relacionada às condições ambientais locais e ao ecossistema (Dan e Chandran, 2011).

Desde o século passado as actinobactérias têm sido relatadas como micro-organismos que apresentam a capacidade de degradar hidrocarbonetos de petróleo (Raymond, Jamison e Hudson, 1967). Existem evidências que demonstram que micro-organismos residentes no solo, podem oxidar ciclohexano e que este mecanismo de oxidação envolve cooxidação. 
Tonge e Higgins (1974) em seu relato utilizou Nocardia petroleophila (NCIB 9438) para indicar a presença de um composto carbonil que foi detectado no meio de cultura na fase de crescimento como 3-metilciclano e 3-metilhexanona.

As actinobactérias são micro-organismos que tem a capacidade de crescer utilizando hidrocarbonetos, como os alicíclicos aromáticos, como fonte de carbono e energia, biodegradando os composto orgânicos poluentes em substâncias com pouca ou nenhuma toxidade (Sorkhoh et al., 1995).

\section{A degradação de n-alcanos}

Algumas bactérias isoladas de solos de campos contaminados com óleo na guerra do Golfo como Pseudomonas, Bacillus, Arthrobacter e Rodococcus mostrou-se eficiente na utilização de n-alcanos como fonte de carbono e energia de $\mathrm{C} 12$ a C 17 e a mais predominante foi Rodococcus , seguido de Bacillus e Arthrobacter (Sorkhoh et al., 1995).

As mudanças que ocorrem na composição do óleo pela ação da microbiota é entendida pelo potencial diversificado entre os diversos gêneros que utilizam a cadeia de alcanos. Exemplos destes micro-organismos são os Rhodococcus, Streptomyces e Pseudomonas (Sorkhoh et al., 1995).

A actinobactéria Thermomonospora fusca foi estudada em processos de degradação de compostos alifáticos através dos intermediários durante o processo (Witt et al., 2003).

Rodococcus, Nocardia e Gordonia, mostraram-se similares no perfil de utilização de hidrocarbonetos através de $\beta$-oxidação de compostos aromáticos. Estes microorganismos, utilizam hidrocarbonetos com uma cadeia lateral alquil em sua estrutura para a produção de uma ampla variedade de lipídios com diferentes complexidades e funções. Esta capacidade das actinobactérias, de transformação sob condições que ocorrem freqüentemente na natureza, fazem destes micro-organismos potencial candidatos para atividades de biorremediação em ambientes contaminados (Alvarez, 2003).

O gênero Rodococcus é um grupo muito diverso de bactéria que possui a capacidade de degradar um grande número de compostos orgânicos, incluindo compostos recalcitrantes e tóxicos. Essa capacidade advém de seus diversos genes catabólicos e sua robusta fisiologia celular (Larkin, Kulakov e Allen, 2005). O potencial para degradação de fenol, clorobenzeno e diclorobenzeno como fonte de carbono, tem sido observada em bactérias Gram positivas, a espécie de actinobacteria Rodococcus phenolicus, foi proposta por Rehfuss e Urban (2006).

\section{Conclusão}

Dentre todos os problemas provocados pelo fenômeno de poluição ambiental, a contaminação por petróleo e derivados tem causado bastante preocupação, seja pela frequência dos eventos ou pelo elevado potencial poluente dos mesmos.

Pode ser observado que a ampla distribuição dos hidrocarbonetos nos ambientes contaminados ocasionam problemas à saúde de humanos e animais, tendo em vista os 
limites impostos pela legislação ambiental, sua eliminação do ambiente deve ser buscada, visando a redução da exposição e da absorção pelos organismos.

Não existem fatores definidos para a escolha de uma determinada técnica de biorremediação, a complexibilidade dos problemas de contaminação de solos e águas pode requerer a combinação de diversas técnicas disponíveis. Um fator a ser considerado na escolha da técnica mais apropriada é a disponibilidade do contaminante no meio ambiente. Como a biodisponibilidade é considerada um fator limitante, é notável que as técnicas de biorremediação possam ser observadas pela sua habilidade em aumentar a biodisponibilidade, assim como a biodegradação subsequente dos compostos a serem tratados. 


\section{Referências}

Alvarez, H. M. (2003). Relationship between $\beta$-oxidation pathway and the hydrocarbondegrading profile in actinomycetes bacteria. Chemosphere, 52, 35-42.

Bento, D. M. (2005). Análise Química da Degradação dos Hidrocarbonetos de Óleo Diesel no Estuário da Lagoa dos Patos. Dissertação (Mestrado em Oceanografia Física, Química e Geológica) - Universidade Federal do Rio Grande, Rio Grande.

Castelo-Grande, L., Augusto, P. A. \& Barbosa, D. (2009). Técnicas de Descontaminação de Solos: uma revisão. Endereço: http://dme.uma.pt/people/faculty/herlander.lima/ Doc\%20 ImpactesAmbientais/05SOLO_Descontaminacao_Ingenium.pdf. Acesso em: $12 / 10 / 2009$.

Cunha, M.B. \& Bianchinni - Júmior, I. (2009). Degradação anaeróbica de Cabomba Piauhyensis e Scirpus Cubensis. Cinética de formação de gases. Endereço: http:// www.sblimno.org.br/acta/my_web_sites/acta_limnologica_contents $1101 \mathrm{E}$ _ files/re sumo \%202_11(1).pdf. Acesso em: 24/10/2009.

Das N. \& Chandran P. (2011). Microbial Degradation of Petroleum Hydrocarbon Contaminants: an overview. Biotechnology Research International, 1, 1-13.

De Oliveira, F.J.S. (2001). Biorremediação de Solo Arenoso Contaminado por Óleo Cru. Dissertação. Universidade Federal do Rio de Janeiro, UFRJ. Escola de Química, Rio de Janeiro, Brasil. 110 p.

EMBRAPA. (2009). Biodegradação. Endereço: www.cnpae.embrapa.br/palestras /p3... embrapa.pdf/view. Acesso em: 14/11/2009.

Fernandes, F. M. \& Alcântara, G. Z. (2009). Biorremediação de Solos Estado da Arte. Endereço: http://www.ecobio natureza. com.br / prog / Biorremedia\%C3\%A7\%C3\%A3o\%20de\% 20 Solo.pdf. Acesso em: 25/10/2009.

Freitas, C. M., Souza, M. H., Machado, J. M. H. \& Porto, M. F. S. (2009). Acidentes de trabalho em plataformas de petróleo da Bacia de Campos, Rio de Janeiro, Brasil. Disponível em: http://www.abepro.org.br/biblioteca/ENEGEP 1999_A0335.PDF. Acesso em: 23/11/2009

Geologia da Petróleo. (2009). Endereço: http://mundo petroleo.files.com /20 08 /02/ geologia_do_petroleo.pdf. Acesso em: 03/12/2009.

Hidayati, A. \& Tachibana, S. (2012). Biodegradation of aliphatic hydrocarbon in three types of crude oil by Fusarium sp.F092 under stress with artificial sea water. Journal of Environmental Science and Technology, 5 (1), 64-73.

Hurst, C.J., Knudsen, G.R., MCLnerney, M.J., Stenzenbach, L.D. \& Walter, M.V. (1997). Manual of Environmental Microbiology, Ed: Hurst, C.J., Knudsen, G.R., MCLnerney, M.J., Stenzenbach, L.D., Walter, M.V. Washington DC: American Society for Microbiology, 894p.

Instituto Superior Técnico. (2009). Vias de degradação de compostos aromáticos Xenobióticos. Endereço: www.e-escola.pt/mgallery/default.asp?obj=3054. Acesso em: 05/12/2009.

Jacques, R. J., Bento, F. M. \& Antoniollim, Z. I. (2009). Biorremediação de solos contaminados com hidrocarbonetos aromáticos policíclicos. Endereço: http://www. scielo.br/pdf/cr/v37n4/a49v37n4.pdf. Acesso em: 24/06/2012. 
Larkin, M.J., Kulakov, L.A. \& Allen, C.R. (2005). Biodegradation and Rhodococcus masters of catabolic versatility. Current Opinion in Biotechnology, 16, 282-290.

Lucchesi, C. F. Petróleo. (1998). Endereço: http://www.scielo.br /pdf/ea /v12n33 / v12n33a03.pdf. Acesso em: 19/06/2012.

Mariano, J. B. (2001). Impactos ambientais do refino de petróleo. 216f. Dissertação (Mestrado Ciências em Planejamento Energético) - Universidade Federal do Rio de Janeiro, Rio de Janeiro, Brasil.

Melo, J.M. (2004). Avaliação do Impacto do aumento das concentrações celulares na biodegradação de resíduos oleosos de petróleo. Dissertação de Mestrado (Escola de Química), Universidade Federal do Rio de Janeiro - UFRJ, Rio de Janeiro, Brasil.

Menezes, M. P. (2009). Biorremediação ex-situ de solos contaminados por Petróleo com a adição de material estruturante. Endereço:http://www.google.com.br/search? hl=ptBR $\& \mathrm{r} \quad \mathrm{lz}=1 \mathrm{R} 2 \mathrm{GGLJptBR} \& \mathrm{q}=$ Michel_Menezes_ Andrea_Rizzo+biorremedia\%C3 $\% \mathrm{~A} 7 \% \mathrm{C} 3 \% \mathrm{~A} 3 \mathrm{o} \& \mathrm{btnG}=$ Pesquisar\&meta $=\& \mathrm{aq}=$ null\&oq $=$. Acesso em: 12/10/2009.

Ministério da Agricultura. (2005) Compostagem Caseira de Lixo Orgânico Doméstico. Disponível em: http://www.cnpmf.embrapa.br/publicacoes /circulares/circular_76. pdf. Acesso em: 26/10/2009

Mogiana. (2009). Indústria de Produtos Químicos LTDA. Endereço: http://www. mogiana.com/literatura/visualisa_lit.php?catalogo=20070526_193603.pdf. Acesso em: $24 / 10 / 2009$.

Netto, A. D. P., Moreira, J. C., Arbilla, G., Dias, A. E. X. O., FerreirA, L. F. V., Oliveira, A. S. \& Barek, J. (1999) Avaliação da contaminação humana por hidrocarbonetos policíclicos aromáticos (HPAs) e seus derivados nitrados (NHPAs): uma revisão metodológica. Disponível em: http://www.scielo.br/scielo.php?script=sci arttext\&pid=S0100-404220 00000600010. Acesso em: 14/08/2009.

Petróleo. (2009). Endereço: http://www.aneel.gov.br/aplicacoes/atlas/pdf/07-Petroleo(2). pdf. Acesso em: 16/11/2009.

Quental, N. (2002). A biorremediação de solos contaminados. Endereço: http://www.esb. ucp.pt/gea/myfiles/quem_somos/nuno/naturlink/2002-07-30.pdf. Acesso: 19/10/2009.

Raymond, R.L., Jamison, N.W. \& Hudson, J. O. (1964). Microbial hydrocarbon cooxidation. Applied Microbiology, 15 (4) 857-865.

Santos, R. M.; Leite, S. G. F.; Sobral, L. G. S.; Rizzo, C. L. (2009). Remedição de solo contaminado por petróleo em Biopilhas. Endereço: http://www.portalabpg.org.br/ PDPetro/4/resumos/4PDPETRO_6_2_0321-1.pdf. Acesso em: 25/10/2009.

Secretaria do Estado do Meio Ambiente. Recursos hídricos. (2009). Endereço: http:// www.semarh.al.gov.br/recursoshidricos. Acesso em: 12/11/2009.

Semêdo, L. T. A. S. (1997). Atividade antimicrobiana e celulolítica de actinomicetos isolados de solos brasileiros. Dissertação p. 128 (Mestrado Biotecnologia Vegetal Microbiologia Aplicada) Universidade Federal do Rio de Janeiro, Rio de Janeiro.

Semêdo, L.T.A.S., Linhares, A.A., Gomes, R. C., Manfio, G.P., Alviano, C.S., Linhares, L.F. e Coelho, R.R.R. (2001). Isolation and characterization of actinomycetes from Brazilian tropical soils. Microbiological Research, 155, 291-299. 
Semêdo, L. T. A. S. (2002). Atividade celulolítica de actinomicetos isolados em ambientes naturais e antropogênicos e proposta de uma nova espécie de Streptomyces de importância biotecnológica. 134f. Tese de Doutorado em Ciências - Microbiologia (Instituto de Microbiologia Prof. Paulo de Góes) Universidade Federal do Rio de Janeiro, UFRJ, Rio de Janeiro.

Semêdo, L.T. A. S. (2004). Biorremediação aplicada ao tratamento de poluentes orgânicos e inorgânicos. Apostila do Curso Biorremediação aplicada ao tratamento de poluentes orgânicos e inorgânicos. NADC, UFRJ.

Semêdo, L. T. A. S., Gomes, R. C., Linhares, A.A., Duarte, G. F., Nascimento, R. P., Rosado, A. S., Margis-Pinheiro, M., Margis, R., Silva, K .R. A., Alviano, C. S., Manfio, G. P., Soares, R. M. A., Linhares, L. F. e Coelho, R. R. R. (2004). Streptomyces drozdowiczii sp.nov., a novel cellulolytic streptomycete from soil in Brazil. International Journal of Systematic and Evolutionary Microbiology, 54, 1323-1328.

Silva, M. A.; Melo, R. e Souza, R. R. (2009). Biodegradação de resíduos agrícolas como alternativa à redução de riscos ambientais no semi-árido sergipano. Endereço:http:// www.anppas.org.br/encontro_anual/encontro2/GT/GT05/silva_ma_e_outros.pdf Acesso em: 14/09/2009.

Souza, A. L.; Coelho, R. R. (2004). Especiação de enxofre orgânico via técnicas de IV -TF e modelagem molecular - Determinação em asfaltenos. Endereço: http://www. ppe.ufrj.br/ppe/production/tesis/prdasilva.pdf. Acesso em: 16/10/ 2009.

Sorkhoh, N. A., AL-Hasan, R. H., Khanafer, M. \& Radwan, S. S. (1995). Establishment of oil-degrading bacteria associated with cyanobacteria in oil-polluted soil. Journal Applied Bacteriology, 78, 194-199.

Tonge, G. M \& Higgis, I. J. (1974). Microbial metabolism of alicyclic hydrocarbons. Growth of Nocardia petroleophila (NCIB9438) on methylcyclohexane. Journal of General Microbiology, 81, 521-524.

Trindade J. V. O. (2002). Avaliação das técnicas de bioaumentação e bioestimulação no processo de biorremediação de solo contaminado por hidrocarbonetos de petróleo. Escola de Química, Universidade Federal do Rio de Janeiro.

USP - Universidade de São Paulo. Composição do Petróleo. (2009). Endereço: http://cepa. if.usp.br/energia/energia1999/Grupo1A/composicao.html. Acesso em: 14/09/2009.

Urban, J. \& Rehfuss, M. (2005). Rhodococcus phenolicus sp. nov., a novel bioprocessor isolated actinomycete with the ability to degrade chlorobenzene, dichlorobenzene and phenol as sole carbon sources. Systematic and Applied Microbiology, 28, 695-701.

Williams, S.T.; Sharples, G.P. \& Bradshaw, R.M. (1973). The fine structure of the Actinomycetales, In: Actinomycetales. G. Sykes \& F.A. Skinner (eds). Academic Press. p. 113-130.

Witt, U.; Eining, M. Y.; Kleenberg.; Deckwer, W.D.; Muller, R. J. (2001). Biodegradation of aliphatic-aromatic copolyesters: evaluation of the final biodegradability and ecotoxicological impact of degradation intermediates. Chemosphere, 44, 289-299.

Yergeau, E., Sanschagrin S., Beaumier, D., \& Greer C.W. (2012) Metagenomic analysis of the biorremediation of diesel-contamined Canadian High Arctic Soils. PloS ONE, 7 (1), 1-10. 